\title{
Bullying in students receiving education at secondary stage primary education public schools in Salihli district of Mani- sa/Turkey
}

\section{Manisa ili, Salihli ilçesinde ilköğretim 6. ve 7. sınıf öğrencilerinde akran zorbalığı, etkileyen ve eşlik eden faktörler}

\author{
Cengiz Erdik ${ }^{1},{ }^{*}$ Saliha Özpınar ${ }^{2}$ \\ ${ }^{1}$ Department of Mathematics Education, Akdeniz University, Alanya Faculty of Education, Antalya, Turkey \\ ${ }^{2}$ Department of Public Health/Midwifery, Celal Bayar University,School of Health, Manisa, Turkey \\ Corresponding author: Dr. Saliha Özpınar, Halk Sağlığı Anabilim Dalı/Ebelik Bölümü, Celal Bayar Üniversitesi Sağlık \\ Yüksekokulu, TR-45020 Manisa, Türkiye \\ E-mail: salihaozpinar@gmail.com \\ Received/Accepted: May 21, 2015/May 29, 2015 \\ Conflict of interest: There is not a conflict of interest.
}

\section{SUMMARY}

Objective: The objective of this study was to determine the levels and determinants of bullying in students receiving education at Secondary Stage Primary Education Schools in Salihli District of Manisa.

Methods: The population of this cross-sectional study consisted of 5., 6., 7., 8. grade secondary school students receiving education in the school year of 2012-2013 in Salihli district of Manisa $(\mathrm{n}=5671)$. The sample size was calculated as 720 at a prevalence of $50 \%$ and a significance level of 0.05 by taking the pattern effect as 2 . Three forms were used in collecting the study data; Sociodemographic questionnaire form, peer victimization identification scale and Rosenberg Self Respect Scale. Chi-square statistical analysis and logistic regression analysis were used for analysis of data.

Results: $57.1 \%$ of the study group were aged 13 and older. The age distribution was between 1022 years. $50.6 \%$ were girls $(n=487)$. Gender, social status, life quality perception and self respect were the variables determining the status of victim/persecutor. Persecutor/victim behaviours were observed at a higher rate in male students compared to female students, students with a lower social status compared to students with a higher social status, those perceiving the life quality as bad compared to those perceiving it as good, and students with a low and moderate self respect compared to students with a high self respect.

Conclusion: Peer victimization is a common public health problem for Manisa/Salihli. In order to struggle with this problem, it is required to develop intervention programs comprising the entire school, family and society in accordance with the Turkish culture.

Keywords: Bullying, persecutor, victim, adolescent

\section{ÖZET}

Amaç: Çalışmanın amacı, Manisa İli Salihli İlçesi Merkezindeki İlköğretim İkinci Kademe öğrencilerinde akran zorbalığı düzeylerinin ve belirleyicilerinin saptanmasıdır.

Yöntem: Kesitsel tipteki bu araştırmanın evrenini Manisa İli Salihli İlçe merkezinde bulunan 2012-2013 yılında eğitim- öğretim gören orta öğretim 5,, 6, 7,, 8. Sinıf öğrencileri oluşturmaktadır (n=5671). Örnek büyüklüğü desen etkisi 2 alınarak, \%50 prevalans ve 0,05 yanılg1 düzeyinde 720 olarak hesaplandı. Çalışma verilerinin toplanmasında üç form kullanıldı; Sosyodemografik anket formu, Akran zorbalığı belirleme ölçeği ve Rosenberg Benlik Saygısı Ölçeği. Verilerin analizinde ilk aşamada ki-kare istatistik analizi kullanıldı. Ki-kare analizlerinde fark çıkan değişkenler lojistik 
regresyon analizi ile değerlendirildi.

Bulgular: Araştırma grubunun \%57,1'i 13 yaş ve üzerindedir. Yaş dağılımı 10-22 yaşları arasında değişmekteydi.. \%50,6'sı kızdır (n=487). Çalışmada kurban/zorba olmayı belirleyen değișkenlerin cinsiyet, sosyal statü, yaşam kalitesi algısı ve benlik saygısı olduğu belirlenmiștir. Erkek öğrenciler kız öğrencilere göre, alt sosyal statüdeki öğrenciler üst sosyal statüye göre, yaşam kalitesini kötü olarak algılayanlar iyi olarak algılayanlara göre ve benlik saygıları düşük ve orta olanlar benlik saygıları yüksek olan öğrencilere göre daha fazla zorba/kurban davranışlarında bulunmaktadırlar.

Sonuç: Akran zorbalığı Manisa/Salihli için yaygın bir halk sağlığı problemidir. Bu problem ile mücadelede Türkiye'ye uygun olarak tüm okulu, aileyi ve toplumu içeren müdahale programları geliştirilmelidir.

Anahtar sözcülkler: Akran zorbalığı, zorba, kurban, ergen

\section{INTRODUCTION}

Adolescence is a transition period between childhood and adulthood with rapid anatomical, physiological and psychological changes, as well as distinctive features and problems $^{1,2}$. Many researchers define adolescence as a rough, unbalanced, changeable and stressful period with conflicts, ${ }^{3,4}$. In this period, the adolescent not only tries to harmonise with the growth and development process, but also copes with other problems that are related with this period ${ }^{5}$.

Steinberg (2007) states that friends and peer groups may both contribute to and disable an individual's psychosocial development ${ }^{6}$. One of these is the peer victimization. Initial studies on school victimization were started by Olweus in Scandinavian countries during the 1970 s $^{7}$. Being a pioneer researcher on peer victimization, Olweusakran defined the victimization as "Constant negative actions performed by one or more students on another student" $"$.

Victimization is intensely observed among children and adolescents at schools. In the literature, it is stated that children that are exposed to victimization by their peers or friends are negatively affected by such experiences in both the short and long term ${ }^{9}$. In addition to this, such behaviors have a negative effect upon not only the persecutor and victim, but also other students witnessing the victimization. Depression, suicidal thoughts, psychiatric problems, decrease of self respect and problems with parents are observed more frequently in children who victimize their peers and are exposed to peer victimization $^{10,11}$ Thus, it is important to develop health policies in order to increase the mental health and self respect levels of adolescents and determine the levels of bullying and by which conditions these levels are affected in planning the services or interventions.

No relevant study had been conducted in the province of Manisa before. The objective of the study, which was planned based on that motive, was to determine the levels and determinants of bullying in students receiving education at Secondary Stage Primary Education Schools in Salihli District of Manisa.

\section{MATERIAL AND METHODS}

The population of this cross-sectional study consisted of 5., 6., 7., 8. grade secondary school students receiving education in the school year of 2012-2013 in Salihli district of Manisa $(n=5671)$. The sample size was calculated as 720 at a prevalence of $50 \%$ and a significance level of 0.05 by taking the pattern effect as 2 and using the openepicalcultor program.

The sample selection was multi-staged. In the first stage, we received the names of two schools in different socioeconomic regions from the District National Education Directorate of Manisa/Salihli in determining the schools to be involved in the sample. In the second stage, each branch of 5., 6., 7. and 8. grades of all schools were evaluated as clusters. The average branch size in each cluster was determined, and since the smallest branch size was 40 , the cluster size was accepted as 40 and the number of clusters to be obtained from each class (5., 6., 7. and 8. Grades) was determined. In the study, it was decided to obtain only one branch from each class in order to remove the effect of education.

Three forms were used in collecting the study data; Sociodemographic question- 
naire form, peer victimization identification scale and Rosenberg Self Respect Scale.

Sociodemographic questionnaire form: It involves 20 questions about students' age, gender, class, mother's age, father's age, mother's education, father's education, family type, number of siblings, social status, life quality and school attitude. In the study, the questions of HBSC (Health Behaviour in School-aged Children) school attitude questionnaire were used in measuring the school attitudes. Values between 1-5 were given for each item in the school attitude evaluation and the total score was obtained. Those receiving an average and higher score from the total score were evaluated to have a good school attitude ${ }^{12}$. In the study, the classificiation of lower and upper social classes was evaluated according to fathers' jobs of students as follows; employers, high-quality independent businessmen,craftsmen/marginals, high-quality wage earners, white-collars in the upper social class; unskilled duties labourers, blue-collars and the unemployed in the lower social class ${ }^{13}$.

Bullying identification scale: The scale was developed by Pişkin and Ayas. Confirmative factor analysis was performed for its construct validity. As a result of the confirmative factor analysis, it was determined that the model involving 37 items and five factors was theoretically and statistically convenient. Cronbach Alpha internal consistency coefficients were calculated for the reliability of the scale. The internal consistency coefficient of the victim dimension of the scale was determined as. 90. The internal consistency coefficient of the persecutor dimension of the scale was determined as $.87^{14}$. In our study, while the internal consistency coefficient of the victim dimension of the scale was determined as. 90, the internal consistency coefficient of the persecutor dimension was determined as 71 .

Rosenberg self respect scale: It was developed by Rosenberg (1965). The Turkish validity and reliability study of the scale was performed by Çuhadaroğlu (1986) and the validity coefficient was determined as 0.71 . The reliability coefficient was deter- mined as 0.75 by using the test-retest reliability method. In this study, the Rosenberg Self Respect Scale alpha value was determined as 0.65 . The first " 10 " items of the scale were used to measure the self respect in line with the objective of the study. Each item involves answer choices as "Highly true", "True", "False" and "Highly false". If the total score that is obtained from the first 10 questions is $0-1$, the self respect is high; if it is 2-4, the self respect is moderate and if it is 5-6, the self respect is low ${ }^{17,18}$.

In order to conduct the study, a research permission was obtained from the Branch Office of the National Education and an informed consent from students. Volunteer students were involved in the study. The study data were collected from students in classes under the supervision of the researcher with the questionnaire technic. Each questionnaire was filled in approximately 40 minutes.

\section{Statistical analysis}

The study data were evaluated in the SPSS 15.0 statistics packaged software. Chisquare statistics analysis was used in the first stage of the data analysis. Variables that were observed to have a difference in the chi-square analysis were evaluated with the logistic regression analysis.

\section{RESULTS}

$57.1 \%$ of the study group were aged 13 and older. The age distribution was $12.8 \pm$ $1.2(10-22) .50 .6 \%$ were girls $(n=487)$. While the age distribution of mothers was $38.0 \pm 5.5$ (24-60), the age distribution of fathers was $41.7 \pm 6.0$ (24-72). $78.1 \%$ $(\mathrm{n}=752)$ of mothers' education and $73.6 \%$ $(\mathrm{n}=709)$ of fathers' education was primary and lower education. $82.8 \%(n=797)$ stated that their income met their expenditure and $7.2 \%(n=69)$ had a job outside of school (Table 1).

In the study group, the distribution of peer victimization is given in Table 2. As a result of the study, $42.9 \%(n=413)$ of students were determined to be persecutors, $100 \%(n=963)$ victims and $40.2 \%(n=387)$ persecutors/victims. Examining the distribution of peer victimization according to the subfields of peer victimization; $24.1 \%$ $(n=232)$ of students displayed physical 
victimization, $23.5 \%(\mathrm{n}=226)$ verbal victimization, $17.4 \%(\mathrm{n}=168)$ exclusion, $8.8 \%$ $(n=85)$ gossips and $12.6 \%(n=121)$ vandalism. All the students were exposed to physical victimization. $43.7 \% \quad(n=421)$ were exposed to (victimized by) verbal victimization, $31.7 \% \quad(n=305)$ exclusion,
$25.0 \%(\mathrm{n}=241)$ gossips and $25.8 \%(\mathrm{n}=248)$ vandalism. $24.1 \% \quad(\mathrm{n}=232)$ of students were physical persecutors/victims. $21.0 \%$ $(n=202)$ were persecutors/victims in verbal victimization, $14.3 \% \quad(\mathrm{n}=138)$ exclusion, $7.4 \%(n=71)$ gossips and $28.5 \%(n=274)$ vandalism (Table 2).

Table 1: Social -Demographic properties of experimental group.

\begin{tabular}{|c|c|c|c|}
\hline \multicolumn{2}{|c|}{ Characteristic } & $\mathbf{N}$ & $\%$ \\
\hline Age & $\begin{array}{l}\text { Under } 13 \\
13 \text { and over }\end{array}$ & $\begin{array}{l}413 \\
550 \\
\end{array}$ & $\begin{array}{l}42.9 \\
57.1\end{array}$ \\
\hline \multicolumn{2}{|l|}{ Age interval } & \multicolumn{2}{|c|}{$\begin{array}{l}12.8 \pm 1.2(10- \\
22)\end{array}$} \\
\hline Grade & $\begin{array}{l}5 \text { th } \\
6 \text { th } \\
7 \text { th } \\
8 \text { th }\end{array}$ & $\begin{array}{l}166 \\
246 \\
254 \\
297\end{array}$ & $\begin{array}{l}17.2 \\
25.5 \\
26.4 \\
30.8\end{array}$ \\
\hline Gender & $\begin{array}{l}\text { Girl } \\
\text { Boy }\end{array}$ & $\begin{array}{l}487 \\
476\end{array}$ & $\begin{array}{l}50.6 \\
49.4\end{array}$ \\
\hline \multicolumn{2}{|l|}{ Range of mother's age } & \multicolumn{2}{|c|}{$\begin{array}{l}38.0 \pm 5.5(24- \\
60)\end{array}$} \\
\hline Education level of the mother & $\begin{array}{l}\text { Upper primary education } \\
\text { Primary education and lower }\end{array}$ & $\begin{array}{l}211 \\
752 \\
\end{array}$ & $\begin{array}{l}21.9 \\
78.1\end{array}$ \\
\hline \multicolumn{2}{|l|}{ Range of father's age } & \multicolumn{2}{|c|}{$41.7 \pm 6(24-72)$} \\
\hline Education level of the Father & $\begin{array}{l}\text { Upper primary education } \\
\text { Primary education and lower }\end{array}$ & $\begin{array}{l}254 \\
709 \\
\end{array}$ & $\begin{array}{l}26.4 \\
73.6\end{array}$ \\
\hline Social statues & $\begin{array}{l}\text { high } \\
\text { low }\end{array}$ & $\begin{array}{l}564 \\
399 \\
\end{array}$ & $\begin{array}{l}58.6 \\
41.4\end{array}$ \\
\hline Years of residence in the region & $\begin{array}{l}\geq 10 \text { years } \\
<10 \text { years }\end{array}$ & $\begin{array}{l}664 \\
299\end{array}$ & $\begin{array}{l}69.0 \\
31.0\end{array}$ \\
\hline Has a job outside the school & $\begin{array}{l}\text { yes } \\
\text { no }\end{array}$ & $\begin{array}{l}894 \\
69\end{array}$ & $\begin{array}{l}62.8 \\
7.2\end{array}$ \\
\hline Has a social security & $\begin{array}{l}\text { yes } \\
\text { No }\end{array}$ & $\begin{array}{l}729 \\
23\end{array}$ & $\begin{array}{l}75.7 \\
24.3\end{array}$ \\
\hline Income perception & $\begin{array}{l}\text { Income sufficient for expenses } \\
\text { Income insufficient for expenses }\end{array}$ & $\begin{array}{l}797 \\
166 \\
\end{array}$ & $\begin{array}{l}82.8 \\
17.2\end{array}$ \\
\hline \multicolumn{2}{|l|}{ Total } & 963 & 100.0 \\
\hline
\end{tabular}

Table 2: Peer Bullying Distrubition in Experimental Group, Manisa/Salihli, 2013.

\begin{tabular}{l|l|cc|cc|cc}
\hline & & \multicolumn{2}{|c|}{ Bully } & \multicolumn{2}{c}{ Victim } & \multicolumn{2}{c}{ Bully/Victim } \\
& & $\mathbf{n}$ & $\mathbf{\%}$ & $\mathbf{n}$ & $\mathbf{n}$ & $\boldsymbol{\%}$ & $\mathbf{n}$ \\
\hline Peer bullying & & 413 & 42.9 & 963 & 413 & 42.9 & 963 \\
\hline \multirow{4}{*}{ Peer bullying sub-fields } & Physical Bulling & 232 & 24.1 & 963 & 232 & 24.1 & 963 \\
& Verbal Bulling & 226 & 23.5 & 421 & 226 & 23.5 & 421 \\
& Alienation & 168 & 17.4 & 305 & 168 & 17.4 & 305 \\
& Slandering & 85 & 8.8 & 241 & 85 & 8.8 & 241 \\
& Destruction of property & 121 & 12.6 & 248 & 121 & 12.6 & 248 \\
\hline
\end{tabular}


Table 3: Multiple analysis results for being "Bully" and effected factors in the field of peer bulling in experimental group, Manisa/Salihli, 2013"Bully".

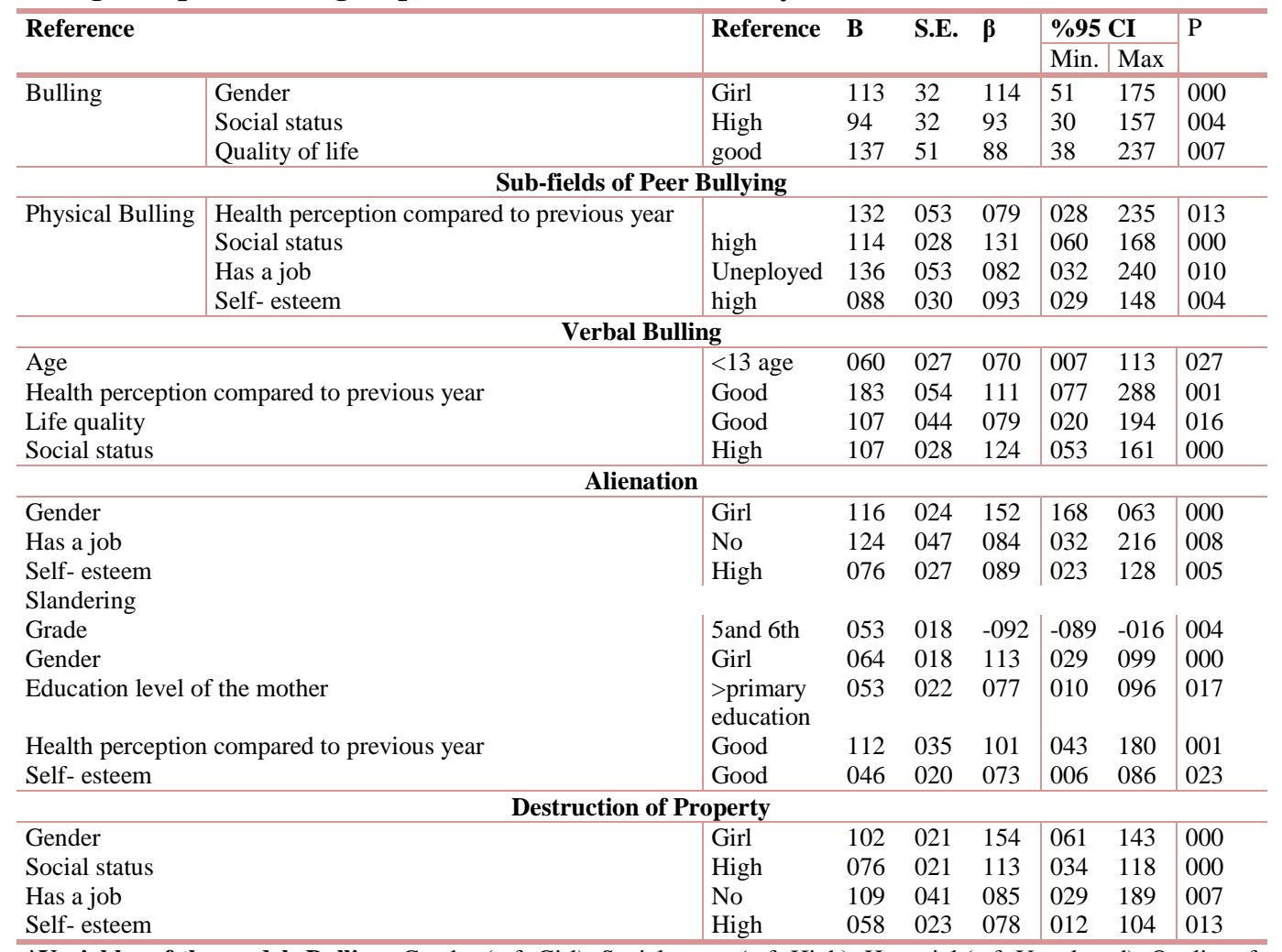

*Variables of the model: Bulling: Gender (ref: Girl), Social status (ref: High), Has a job(ref: Uneployed), Quality of life (ref:good). Physical Bulling: Education level of the mother (ref: >primary education ), Education level of the father (ref: > primary education ), Social status (ref: High), Has a job(ref: Uneployed), Health perception compared to previous year (ref: good), Self- esteem (ref: high), attitudes to school (ref: average score and above). Verbal Bullin: Grade (ref: 5 and6. grade), Age (ref: Under 13), Health perception compared to previous year (ref: good), Social status (ref: High), Quality of life (ref:goodi). Alienation: Gender (ref: Girl), Has a job(ref: Uneployed), Self- esteem (ref: high). Slandering: Age (ref: Under 13), Grade (ref: 5 and6. grade), Gender (ref: Girl), Education level of the mother (ref: >primary education ), perception of income (ref:good), Health perception compared to previous year (ref: good), Has a job(ref: Uneployed), Quality of life (ref:good), Self- esteem (ref: high). Destruction of Property: Gender (ref: Girl), Years of residence in the region (ref: >10 years), Social status (ref: High), Has a job(ref: Uneployed), Self- esteem (ref: high).

Table 3 shows the logistic regression analysis results of being a "persecutor" and the affecting factors in the study group within the scope of peer victimization. According to analyses: gender, social status and life quality perception. Victimizing behaviors are performed at a higher rate by male students compared to female students, students with a lower social status compared to students with a higher social status and those perceiving the life quality as bad compared to those perceiving it as good. Examining the subfields of the peer victimization scale;

- Those in the lower social status, working outside of school, having a lower self respect and expressing a worse health condition compared to the previous year apply physical victimization at a higher rate, compared to others $(\mathrm{p}<0.05)$.
- Students aged thirteen and older, in the lower social status, expressing a worse health condition compared to the previous year and perceiving the life quality as good or moderate apply verbal victimization at a higher rate, compared to others $(\mathrm{p}<0.05)$.

- Male students, as well as those working outside of school and having a lower or moderate self respect apply exclusion at a higher rate, compared to others $(\mathrm{p}<0.05)$.

- Female students, as well as those in the seventh and eighth grade, having mothers with primary or lower education, perceiving their health as worse compared to the previous year and having a lower or moderate self respect make gossips at a higher rate, compared to 
others $(\mathrm{p}<0.05)$.

- Male students, as well as those in the lower social status, working outside of school and having a lower or moderate self respect apply vandalism at a higher rate, compared to others $(\mathrm{p}<0.05)$.

Table 4 shows the logistic regression analysis results of being a "victim" and the affecting factors in the study group within the scope of peer victimization. According to analyses, since all students were exposed to any kind of victimization, being victimized was not compared with variables. Examining the subfields of the peer victimization evaluation scale and exposure to peer victimization;

- All the students (100\%) state that they are exposed to physical victimization.

- Students aged thirteen and older and those perceiving their health as worse compared to the previous year are exposed to verbal victimizatiom at a higher rate, compared to others $(p<0.05)$.

- Male students, as well as those having fathers aged thirty and younger, living in the present region for less than ten years, perceiving their health as worse compared to the previous year and having a lower or moderate self respect are exposed to exclusion at a higher rate, compared to others $(\mathrm{p}<0.05)$.

- Those having mothers with primary or lower education, having fathers aged thirty and younger, living in the present region for less than ten years, perceiving their health as worse compared to the previous year and having a lower or moderate self respect are exposed to gossips at a higher rate, compared to others $(\mathrm{p}<0.05)$.

- Those living in the present region for less than ten years and perceiving their health as worse compared to the previous year are exposed to vandalism at a higher rate, compared to others $(\mathrm{p}<0.05)$.

Table 5 shows the logistic regression analysis results of being a "persecutor/victim" and the affecting factors in the study group within the scope of peer victimization. According to analyses, the variables that determine being a persecutor/victim include gender, social status, life quality perception and self respect. Persecutor/victim behaviors are performed at a higher rate by male students compared to female students, students with a lower social status compared to students with a higher social status, those perceiving the life quality as bad compared to those perceiving it as good and those with a lower and moderate self respect compared to those with a higher self respect. Examining the subfields of the peer victimization scale;

- Students in the lower social status, as well as those not working, perceiving their health as worse compared to the previous year and having a lower or moderate self respect are considered persecutors/victims at a higher rate in terms of physical victimization, compared to others $(\mathrm{p}<0.05)$.

- Students aged thirteen and older, as well as those in the lower social status, perceiving their health as worse compared to the previous year and having a bad life quality are considered persecutors/victims at a higher rate in terms of verbal victimization, compared to others $(\mathrm{p}<0.05)$.

- Male students, as well as those working and having a lower or moderate self respect are considered persecutors/victims at a higher rate in terms of exclusion, compared to others $(\mathrm{p}<0.05)$.

- Male students, as well as those having mothers with primary or lower education, perceiving their health as worse compared to the previous year and having a lower or moderate self respect are considered persecutors/victims at a higher rate in terms of gossips, compared 
to others $(\mathrm{p}<0.05)$.

- Male students, as well as those in the lower social status and having a lower or moderate self respect are considered persecutors/victims at a higher rate in terms of vandalism, compared to others $(\mathrm{p}<0.05)$.

Table 4: Multiple analysis results for being "Victim" and effceted factors in the field of peer bulling in experimental group, Manisa/Salihli, 2013.

\begin{tabular}{|c|c|c|c|c|c|c|c|}
\hline \multirow[t]{2}{*}{ Reference } & \multirow[t]{2}{*}{ Reference } & \multirow[t]{2}{*}{$\mathbf{B}$} & \multirow[t]{2}{*}{ S.E. } & \multirow[t]{2}{*}{$\boldsymbol{\beta}$} & \multicolumn{2}{|c|}{$\% 95 \mathrm{CI}$} & \multirow[t]{2}{*}{$\mathbf{P}$} \\
\hline & & & & & Min. & Max. & \\
\hline \multicolumn{8}{|l|}{$\begin{array}{l}\text { Victom } \\
\text { Peer Bullying Sub-field } \\
\text { Physical Bulling } \\
\text { Verbal Bulling }\end{array}$} \\
\hline Age & Under 13 Good & 081 & 032 & 081 & 018 & 144 & 011 \\
\hline Health condition compared to previous year & Under 13 Good & 256 & 061 & 133 & 135 & 376 & 000 \\
\hline \multicolumn{8}{|l|}{ Alienation } \\
\hline Gender & girl & 092 & 029 & 099 & 034 & 149 & 002 \\
\hline Father's Age & $>30$ age & 282 & 098 & 090 & 089 & 474 & 004 \\
\hline Years of residence in the region & $>10$ years & 107 & 032 & 106 & 044 & 169 & 001 \\
\hline $\begin{array}{l}\text { Health perception compared to previous } \\
\text { year }\end{array}$ & Good & 152 & 057 & 084 & 040 & 263 & 008 \\
\hline Self- esteem & Good & 128 & 033 & 124 & 064 & 193 & 000 \\
\hline \multicolumn{8}{|l|}{ Slandering } \\
\hline Education level of the mother & $>$ primary education & 074 & .033 & 071 & 008 & 139 & 027 \\
\hline Father's Age & $>30$ age & 242 & 092 & 083 & 060 & 423 & 009 \\
\hline Years of residence in the region & $>10$ years & 074 & 030 & 079 & 015 & 132 & 014 \\
\hline $\begin{array}{l}\text { Health perception compared to previous } \\
\text { year }\end{array}$ & Good & 175 & 054 & 104 & 070 & 280 & 001 \\
\hline Self- esteem & Good & 088 & 031 & 091 & 027 & 148 & 004 \\
\hline \multicolumn{8}{|l|}{ Destruction of Property } \\
\hline Years of residence in the region & $>10$ years & 089 & 030 & 094 & 030 & 149 & 003 \\
\hline $\begin{array}{l}\text { Health perception compared to previous } \\
\text { year }\end{array}$ & Good & 165 & 054 & 098 & 059 & 272 & 002 \\
\hline
\end{tabular}

Variables of the model: Victom: This analysis could not be performed. Because all children were exposed. Physical Bulling: This analysis could not be performed. Because all children were exposed. Verbal Bulling: Age (ref: Under 13), Grade (ref: 5 and6. grade), Health perception compared to previous year (ref: good). Alienation: Gender (ref: Girl), Father's Age (ref: $>30$ age); Years of residence in the region (ref: >10 years), perception of income (ref:good), Health perception compared to previous year (ref: good), Has a job(ref: Uneployed), Self- esteem (ref: high). Slandering: Education level of the mother (ref: > primary education ), Father's Age (ref: $>30$ age), Years of residence in the region (ref: $>10$ years), perception of income (ref:good), Health perception compared to previous year (ref: good), Has a job(ref: Uneployed), Quality of life (ref:good), Self- esteem (ref: high). Destruction of Property: Years of residence in the region (ref: >10 years), Health perception compared to previous year (ref: good), Social status (ref: High).

\section{DISCUSSION}

Bullying is an important public health problem that is frequently encountered in the school environment and may cause physical and mental traumas unless prevented $^{15-17}$.

Since prevalences of adolescents regarding victimizing, being exposed to victimization and being involved in a fight may expose these behaviors to a cultural sanction, they show a great geographical variance ${ }^{9}$. In the study, $42.9 \%$ of students were determined as persecutors, $100 \%$ victims and $40.2 \%$ persecutors/victims. The most frequent victimizing behavior is the physical victimization with a rate of $24.1 \%$, which is followed by verbal victimization $(23.5 \%)$ and exclusion (17.4\%). Similarly, victims are mainly exposed to the physical victimization. However, the fact that this rate is
$100 \%$ is very important. It is followed by verbal victimization $(43.7 \%)$ and exclusion $(31.7 \%)$. Similarly, the physical victimization, verbal victimization and exclusion are ranked top three in being a persecutor or victim (respectively as $24.1 \%, 21.0 \%$ and $14.3 \%$ ). Examining the relevant studies that were conducted abroad; the persecutor rates, which were obtained as a result of an international study concerning the health behaviors of school-age children that was conducted in cooperation with the European Region Office of World Health Organization, vary between $1-27 \%$ (average 9\%) for the age $11,1-35 \%$ (average 12\%) for the age 13 and $2-34 \%$ (average 12\%) for the age 15 among countries ${ }^{12,18}$. As a result of a study that was conducted in Italy, it was determined that $56.5 \%$ were exposed to victimization and $49.5 \%$ performed 
victimization 33 of students were persecutors, 19 victims and 7 persecutors/victims ${ }^{19}$. It was also determined that $36 \%$ of students in South Africa were involved in victimizing behaviors. $8.2 \%$ of these students were persecutors, $19.3 \%$ victims and $8,7 \%$ persecutors/victims. The rate of being victims, persecutors and persecutors/victims was respectively determined as $14 \%, 17 \%$ and $9 \%$ in Korea in $2000^{20}$. Examining the relevant studies in our country; Alikaşifoğlu et al. reported that $22 \%$ were only victims, $9.4 \%$ persecutors/victims and $9.2 \%$ only persecutors in $2007^{21}$. The rate of those that were exposed to physical, verbal, emotional and sexual victimization was determined respectively as $33.5 \%, 35.3 \%, 28.0 \%$ and $15.6 \%$ in Ankara during the school year of 2000$2001^{22}$. In his study that was conducted in 2003, Pişkin determined the rate of victims as $35 \%$, the rate of persecutors/victims as $30 \%$ and the rate of persecutors as $6 \%$. It was reported that $34 \%$ of students were exposed to physical victimization, $29 \%$ verbal victimization, $21 \%$ indirect victimization (isolation) and $11 \%$ were exposed to victimization by vandalism. Students stated that they were mainly exposed to the victimizing words and actions of their classmates $(52 \%)^{23}$. Examining the literature findings; it is seen that different regions involve different frequencies, which could be explained by the fact that peer victimization is affected by cultural features.

In our study, it was determined that male students were persecutors/victims and displayed victimizing behaviors at a higher rate, compared to female students. It is also stated in literature that victimization is observed in boys at a higher rate compared to girls ${ }^{18,24,25}$. Study findings show a parallelism with the literature.

As a result of the study, it was determined that students aged 13 and older were either persecutors, victims or persecutors/victims in "verbal victimization". However, students aged 13 and older displayed less victimizing behaviors in "making gossips", compared to students younger than 13 . Examining the relevant literature; according to the data of the study dated 20052006 regarding the health behaviors of school-age children, victimization is encountered more frequently in the age group of 13, compared to the age group of 11 in many countries. On the other hand, the rates of being victimized progress in a relatively stable way. 8 Olweus stated that there was a distinct decrease in being exposed to victimizing actions in parallel with age, whereas there was no change in the frequency of displaying victimization ${ }^{26}$. In another study that was performed by Boulton\&Underwood (1992) with secondary school students, it was observed that there was a decrease in victim rates and an increase in victimization rates in parallel with age, which shows a similarity with Olweus's study ${ }^{27}$. Even though the literature findings generally suggest that the frequency of displaying victimizing actions increases and the frequency of being victimized decreases in parallel with age, it is not possible to make a generalization.

In the study, it was determined that while children in every social status were exposed to peer victimization, children in the lower social status displayed victimizing behaviours at a higher rate compared to others. Some studies in the literature have failed to clearly determine the relationship between the socioeconomic condition of families and peer victimization. In the study dated 2005-2006 regarding the health behaviors of school-age children, the relationship between the socioeconomic level and being a persecutor was observed to be differing from country to country. This relationship is either positive or negative in some countries and not available in majority of them. The relationship between the frequency of being a victim and socioeconomic level differs from country to country and no relationship was determined between any of the majority of the examined countries. On the other hand, it is observed that as the socioeconomic level decreases, the frequency of being a victim increases in all of the countries where a relationship is determined ${ }^{12}$.

In the study, it was determined that children applying peer victimization and being both persecutors and victims had a lower life quality and self respect compared to others and perceived their health as worse compared to the previous year. In the liter- 
ature, it is accepted that children being exposed to victimization are in the risk group in terms of many psychological variables ${ }^{9}$. It is stated that children being exposed to victimization need more psychological support, have a higher level of depression and anxiety and a lower level of self respect ${ }^{28}$. In addition to this, it is indicated in literature that persecutor/victim students, in other words, those both victim- izing and being exposed to victimization are individuals that are the least popular and favored among their friends, could incite others and be easily incited, display hyperactivity, restlessness, carelessness, nuisance, as well as neurotic and psychotic features, and have lower levels of social acceptance and self respect ${ }^{27,29}$. The study results show a parallelism with the literature.

Table 5: Multiple analysis results for being "Bully/Victim" and effected factors in the field of peer bulling in experimental group, Manisa/Salihli, 2013.

\begin{tabular}{|c|c|c|c|c|c|c|c|}
\hline \multirow[t]{2}{*}{ Reference } & \multirow[t]{2}{*}{ Reference } & \multirow[t]{2}{*}{ B } & \multirow[t]{2}{*}{ S.E. } & \multirow[t]{2}{*}{$\beta$} & \multicolumn{2}{|c|}{$\% 95 \mathrm{CI}$} & \multirow[t]{2}{*}{$\mathbf{P}$} \\
\hline & & & & & Min. & Max. & \\
\hline \multicolumn{8}{|l|}{ Bully/Victom } \\
\hline Gender & Girl & 096 & 031 & 098 & 035 & 157 & 002 \\
\hline Social status & High & 090 & 032 & 091 & 027 & 153 & 005 \\
\hline Life quality & Good & 129 & 050 & 083 & 030 & 227 & 010 \\
\hline Self- esteem & Good & 075 & 035 & 069 & 007 & 144 & 032 \\
\hline \multicolumn{8}{|l|}{ Sub-fields of Peer Bullying } \\
\hline \multicolumn{8}{|l|}{ Physical Bulling } \\
\hline Social status & Girl & 090 & 030 & 104 & 031 & 149 & 003 \\
\hline Has a job & No & 133 & 053 & 080 & 030 & 237 & 012 \\
\hline Health perception compared to previous year & Good & 129 & 053 & 078 & 026 & 233 & 015 \\
\hline Self- esteem & High & 089 & 030 & 093 & 030 & 148 & 003 \\
\hline \multicolumn{8}{|l|}{ Verbal Bulling } \\
\hline Age & $<13$ age & 063 & 026 & 077 & 012 & 115 & 016 \\
\hline Social statu & Good & 092 & 027 & 112 & 040 & 144 & 001 \\
\hline Health perception compared to previous year & Good & 166 & 052 & 105 & 064 & 267 & 001 \\
\hline Life quality & Good & 093 & 043 & 072 & 009 & 177 & 031 \\
\hline \multicolumn{8}{|l|}{ Alienation } \\
\hline Gender & Girl & 099 & 022 & 141 & 055 & 142 & 000 \\
\hline Has a job & No & 114 & 043 & 084 & 029 & 199 & 009 \\
\hline Self- esteem & Good & 085 & 025 & 109 & 036 & 134 & 001 \\
\hline \multicolumn{8}{|l|}{ Slandering } \\
\hline Gender & Girl & 050 & 017 & 096 & .018 & 083 & 003 \\
\hline Education level of the mother & $\begin{array}{l}\text { >primary } \\
\text { education }\end{array}$ & 051 & 020 & 081 & 011 & 091 & 012 \\
\hline Health perception compared to previous year & Good & 077 & 033 & 076 & 012 & 142 & 020 \\
\hline Self- esteem & Good & 044 & 019 & 075 & 007 & 080 & 019 \\
\hline \multicolumn{8}{|l|}{ Destruction of Property } \\
\hline Gender & Girl & 080 & 019 & 134 & 042 & 117 & 000 \\
\hline Social statu & High & .066 & .019 & .109 & .028 & .104 & .001 \\
\hline Self- esteem & & .048 & .021 & .071 & .006 & .089 & .024 \\
\hline \multicolumn{8}{|c|}{$\begin{array}{l}\text { Variables of the model: Bully/Victom: Gender (ref: Girl), Social status (ref: High), Years of residence in the } \\
\text { region (ref: > } 10 \text { years), Quality of life (ref:good), Self- esteem (ref: high). Physical Bulling: Education level of } \\
\text { the mother (ref: >primary education), Education level of the father (ref: >primary education ), Social status (ref: } \\
\text { High), Has a job(ref: Uneployed), Health perception compared to previous year (ref: good), attitudes to school } \\
\text { (ref: average score and above), Self- esteem (ref: high). Verbal Bulling: Age (ref: Under 13), Grade (ref: } 5 \\
\text { and6. grade), Social status (ref: High), Health perception compared to previous year (ref: good), Quality of life } \\
\text { (ref:good). Alienation: Gender (ref: Girl), Years of residence in the region (ref: >10 years), Has a job(ref: } \\
\text { Uneployed), Self- esteem (ref: high). Slandering: Gender (ref: Girl), Education level of the mother (ref: >prima- } \\
\text { ry education ), Has a job(ref: Uneployed), perception of income (ref:good), Health perception compared to } \\
\text { previous year (ref: good), Quality of life (ref:good), Self- esteem (ref: high). Destruction of Property: Gender } \\
\text { (ref: Girl), Social status (ref: High), Has a job(ref: Uneployed), Self- esteem (ref: high). }\end{array}$} \\
\hline
\end{tabular}

In the study (in single analyses), the school attitude was determined to be worse in those displaying the physical victimization behavior (both persecutors and victims), compared to others. Since the study determined that all the children were exposed to physical victimization, no statistical evaluation was performed among the victims in this area. In peer victimization, the lowness of persecutor/victim students' school attitudes is an expected result. That is to say, a victimized child will start to dislike the school where the victimization has occurred, experience fear and anxiety, be absent from school on every occasion in order to avoid victimization and consequently have a decreased academic achievement, apply methods such as carry- 
ing arms and knives to defend her/himself and display victimizing behaviors. In addition to all these, it seems inevitable for them to also experience various psychological problems. A negative school attitude will also affect the success levels of students negatively. The reasons of this condition is that it will make positive contributions for adolescents, who spend an important part of their lives at school, to have a good level of school satisfaction, accept the educational values, have a good motivation and adopt the school. The school dissatisfaction, which is the contrary, will cause a lower success ${ }^{30,31}$.

In conclusions; as a result of the study, it was established that variables which determined being a persecutor/victim involved gender, social status, life quality perception and self respect. Male students, as well as those in the lower social status, perceiving the life quality as bad and having a lower or moderate self respect display persecutor/victim behaviors at a higher rate, compared to others. While male students, as well as those in the lower social status and having a lower life quality display victimizing behaviors at a higher rate compared to others, all students are exposed to victimizing behaviors, which is an important finding. The most frequently displayed and exposed victimizing behavior is the physical victimization. Peer victimization is a common public health problem for Manisa/Salihli. In order to struggle with this problem, it is required to develop intervention programs comprising the entire school, family and society in accordance with the Turkish culture. Experts in the disciplines of health, education and psychology are required to cooperate in the stages of discussing about the importance of the subject and the required interventions, as well as producing policies.

\section{REFERENCES}

1. Sayıl M, Uçanok Z, Güre A. A descriptive study of emotinal needs, concerns, parent-adolescent conflicts and self concept in puberty. Turkish Journal of Child and Adolescent 2002; 3: 155-66.

2. Odağ C, Tamar M. The Stage of adolescence: A critical phase in the formation of the superego. Turkish Journal of Child and Adolescent 2002; 9: 190-8.

3. Güney M. Depression in adolescent. World of Psychiatry 1998; 2: 41-4.

4. Koç M. Terms of developmental psychology of adolescence and general properties. Journal of the institute of social sciences 2004; 2 : 231-56.

5. Altıparmak S, Taner S,, Türk SM, Eser E. The quality of life in adolescent in secondary public schools in Bornova/Izzmir. Anatolian Journal of Psychiatry 2012; 13: 167 73.

6. Steinberg LS. Ergenlik. Ankara: İmge Kitabevi Yayınları 2007.

7. Koç Z. School bullying: Definition, causes and preventing measures. Journal of World Teachers 2006; 1: 7-12.

8. Olweus D. A useful evaluation design and effects of the Olweus Bullying Prevention Program. Psychology, Crime \& Law 2005; 11: 389-402.

9. Due P, Holstein BE, Lynch J. Bullying and symptoms among school-aged children: international comparative cross sectional study in 28 countries. Eur $\mathbf{J}$ Public Health 2005; 15: 128-32.

10. Alikaşifoglu M. Erginöz E, Ercan O. Violent behaviour among Turkish high school students and correlates of physical fighting. Eur J Public Health 2004; 14: 173-7.

11. Dake JA, Price JH, Telljohann SK The nature and extent of bullying at school. J Sch Health 2003; 73: $173-80$

12. Health behaviour in school-aged children international report from the2005/2006Survey.http://www.e uro.who.int/Document/E91416.pdf . Access: 20.06.2015.

13. Manisa Demographic Health Survey Manual. Celal Bayar University School of Medicine. Department of Public Health. Manisa 2003.

14. Pişkin M, Ayas T. Peer bullying scale child form. Akademik Bakış 
Dergisi 2001; 23: 1-12.

15. Rosenberg M. Society and the Adolescent Self-Image. New Jersey: Princeton University Press 1965.

16. Dereboy İF, Dereboy Ç, Coşkun A, Coşkun B. Self-concept, selfesteem and sense of identify. Çocuk ve Gençlik Ruh Sağlığı Dergisi 1994; 1: 3-12.

17. Özcebe H, Ulukol B, Mollahaliloğlu S, Yardım N, Karaman F. T.C. Sağlık Bakanlığı Sağlık Hhizmetlerinde Okul Sağlığı kitabı. Ankara: Yücel Ofset Matbaacılik 2008.

18. Baldry AC, Farrington DP. Types of bullying among Italian school children. Journal of Adolescence 1999; 22: 423-6.

19. Ivarsson $T$, Broberg AG, Arvidsson T, Gillberg C. Bullying in adolescence: psychiatric problems in victims and bullies as measured by the Youth Self Report (YSR) and the Depression Self-Rating Scale (DSRS). Nord J Psychiatry 2005; 59: 365-73.

20. Kim YS, KohYJ, Leventhal BL. Prevalence of school bullying in Korean middle school students. Arch Pediatr Adolesc Med 2004; 158: 737-41.

21. Alikaşifoglu M, Erginöz E, Ercan O. Bullying behaviours and psychosocial health: results from a cross-sectional survey among high school students in Istanbul, Turkey. Eur J Pediatr 2007; 166: 1253-60.

22. Kepenekci YK, Cinkir S. Bullying among Turkish high school students. Child Abuse Negl 2006; 30: 193-204.

23. Pişkin M. Common problem in our schools: School bullying. VII. National Counseling and Guidance Congress(Congress Book).Malatya 2003; 9-11: 125.

24. Dussich JPJ, Maekoya C. Physical child harm and bullying-related behaviors. International Journal of Offender Therapy and Comparative Criminology 2007; 51: 495509.

25. Nansel T, Craig W, Overpeck MD,
Saluja G, Ruan WJ. Cross-national Consistency in the Relationship Between Bullying Behaviors and Psychosocial Adjustment, Arch Pediatric Adolescent Medicine 2004; 158: 730-36.

26. Olweus D. Bullying or peer abuse at school: Facts and intervention. Current Directions in Psychological Science 1995; 4: 196-200.

27. Pişkin M. School bullying: Definition, types, related factors, and strategies to prevent bullying problems, Educational Sciences. Theory \& Practice 2002; 2: 531-62.

28. Craig WM. The relationship among bullying, victimization, depression, anxiety and aggression in elementary school children. Personality and individual differences 1998; 24: 123-30.

29. Konishi C, Hymel S. Bullying and Stress in Early Adolescence. Journal of Early Adolescence 2009; 29: 333-56.

30. Mok MMC, Flynn M. Does school size affect quality of school life? Issues Educ Res 1997; 7: 69-86.

31. Mok MMC. Flynn. Students' perceptions of social studies: A study of middle school and high school students in Jordan. International Journal of Scholarly Academic Intel- lectual Diversity 2004; 8: 3-13. 